\title{
On the Course of Absorption and the Position of Equilibrium in the Intake of Dyes by Discs of Plant Tissue.
}

\author{
BY \\ GLADYS M. REDFERN, M.Sc., \\ University College, Reading.
}

With eight Figures in the Text.

INTRODUCTION.

THE problem of the absorption of dyes by plant tissue has been the subject of much investigation, especially of late years, but few quantitative data are available. One of the first investigators to examine the problem was Pfeffer (4), whose researches established the fact that many dyes, especially those known as 'intra-vitam stains', are absorbed from very dilute solutions by plant tissue and accumulate in the cells, either as a soluble compound in the cell sap, or as a solid precipitate; various substances in the living cell render the accumulation of the dye possible, the best known being tannin and phloroglucin, which form 'non-diosmosing' compounds with the dyes. Pfeffer also demonstrated the fact that normal growth continues provided that the external solution is sufficiently dilute.

Later workers confirmed many of Pfeffer's conclusions, and established the fact that a larger proportion of dye is absorbed from more dilute solutions. The explanation which was usually accepted was that the dye diffused through the 'plasma membrane' by a process of osmosis, and that the concentration gradient was maintained by the formation of non-diosmosing compounds, as described by Pfeffer.

Recently, however, Moore and his co-workers (3) have challenged the theory that the entrance of substances into the cell can be explained as a process of osmotic diffusion through a semi-permeable membrane; they explain the powers of selective absorption shown by the cell by the supposition that 'the cell protoplasm has selective adsorptive powers for different ions, and that such ions exist in the cell in combination or adsorption with the cell substance'.

Stiles and Kidd (6), in experiments on the influence of external concen[Annals of Botany, Vol. XXXVI. No. CXLIV. October, 1922.] 
tration on the intake of salts by plant cells, found that the relation between final internal concentration and final external concentration was given by the adsorption equation $y=k c^{\frac{1}{m}}$, where $y=$ final internal concentration, $c=$ final external concentration, and $k$ and $m$ are constants. They declined to put forward any proposals as to the mechanism of salt intake by the cell, on the ground that the data available were insufficient to justify any conclusions.

It is a well-known fact that many substances, e.g. charcoal, form adsorption compounds with dyes and will decolorize a solution of dye with which they are in contact.

The present investigation was undertaken in order to obtain quantitative data as to the course of absorption of dyes by plant tissue, and also to determine whether the results would furnish any evidence in favour of the adsorption theory of absorption put forward by Moore and Roaf.

\section{METHODS.}

The method of experimentation employed was similar to that elaborated by Stiles and Jørgensen in their 'Studies in Permeability' ( 7$)$. Storage tissue of various species was used; in practice it was found that the best results were obtained with carrot tissue, and accordingly this tissue was employed in most of the experiments, though potato, artichoke, and turnip were also used. Cylinders of tissue were cut out by means of a cork-borer, $2 \mathrm{~cm}$. in diameter; discs I $\mathrm{mm}$. in thickness were cut with a hand microtome. The discs were thoroughly mixed and washed in two or three changes of distilled water ; they were then weighed in sets of two or four, and immersed in 50 c.c. of the experimental liquid, in corked bottles. The discs were weighed at intervals, in order that evidence might be obtained as to whether the tissue was in a healthy condition, or was injured by the dye. The concentration of the dye in the external solution was estimated colorimetrically; each experiment was performed in duplicate.

The observations were continued in each experiment until equilibrium was established, or until the colour of the dye in the external solution was so changed that a comparative estimation of the concentration was impossible.

A number of water-soluble dyes were used, and in each case four concentrations were employed-0.1 per cent., 0.05 per cent., 0.01 per cent., 0.005 per cent.

In addition to experiments with living tissue, a few series of experiments were carried out with tissue which had been killed in a mixture of absolute alcohol and acetic acid before immersion in the experimental solution. A few experiments were also made to determine the influence of temperature on the absorption of dyes. 


\section{EXPERIMENTAL RESULTS.}

Series I. Experiments with living tissue.

Discs of living tissue, prepared as described in the preceding section, were immersed in solutions of the following water-soluble dyes: neutral red, methylene blue, methyl violet, aniline blue, eosin, and Congo red.

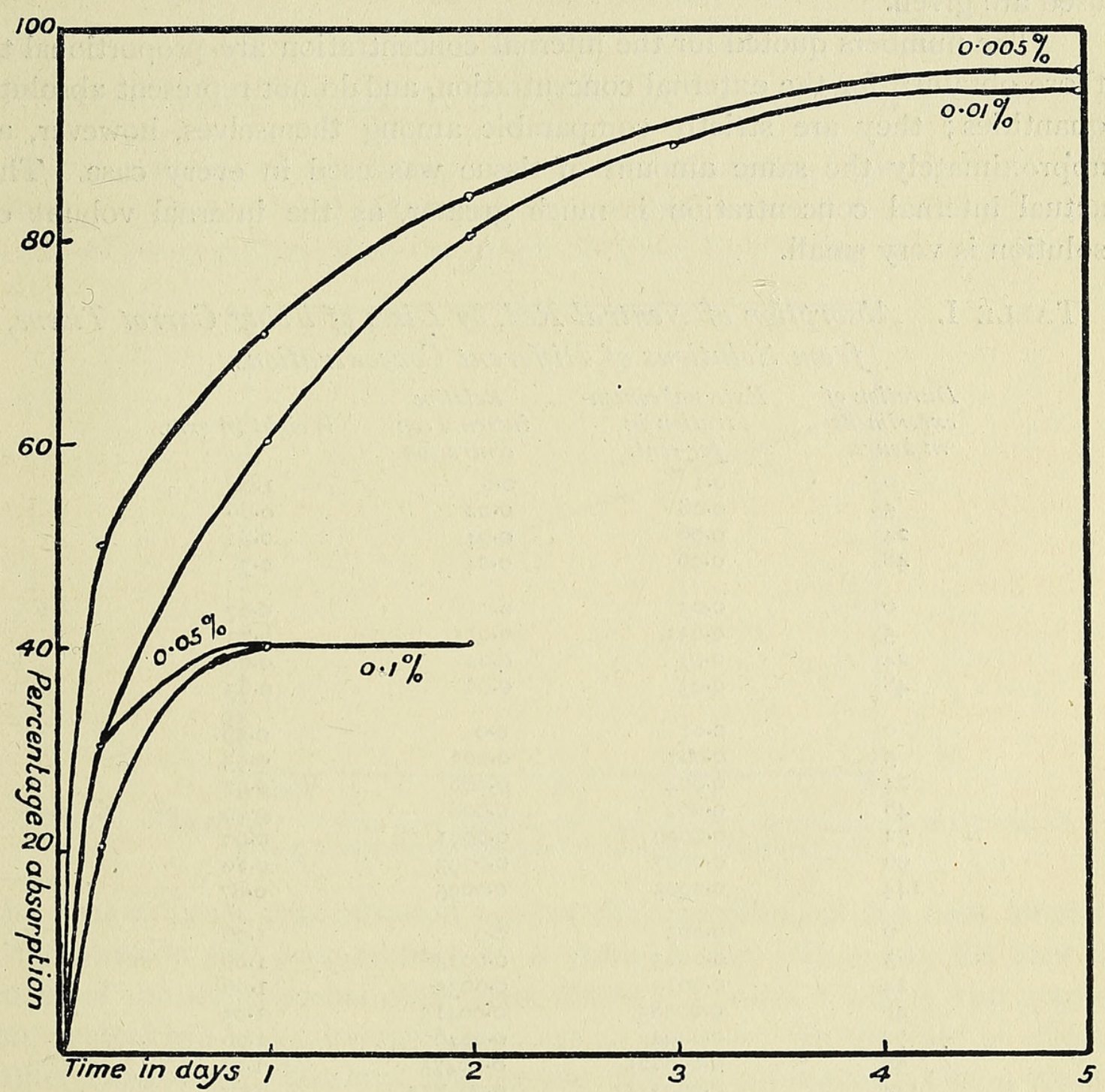

FIG. I. Course of absorption of neutral red, by living carrot tissue, from solutions of various concentration.

The concentration of dye in the external solution was estimated at intervals, and the tissue was weighed.

The results were similar in the case of all the basic dyes employed except aniline blue; the latter dye was not absorbed in appreciable quantity from the more concentrated solutions, and the amount absorbed from the more dilute solutions was small in comparison with the other basic dyes. The results obtained with the acid dye, eosin, resembled those obtained with aniline blue, while Congo red, the only other acid dye used, was not 


\section{I4 Redfern.-On the Course of Absorption and the Position of}

absorbed in appreciable quantity from any concentration. In the cases of aniline blue and eosin, equilibrium was attained very rapidly, and no curves of absorption could be plotted.

In Table I the results obtained with neutral red are summarized, and the curves of absorption are plotted in Fig. I.

In Tables II and III the final external concentrations of all the dyes used are given.

The numbers quoted for the internal concentration are proportional to those obtained for the external concentration, and do not represent absolute quantities; they are strictly comparable among themselves, however, as approximately the same amount of tissue was used in every case. The actual internal concentration is much greater, as the internal volume of solution is very small.

TAble I. Absorption of Neutral Red, by Discs of living Carrot Tissue, from Solutions of Different Concentrations.

$\begin{array}{cclc}\begin{array}{c}\text { Duration of } \\ \text { experiment } \\ \text { in hours. }\end{array} & \begin{array}{c}\text { External concen- } \\ \text { tration in } \\ \text { per cent. }\end{array} & \begin{array}{c}\text { Relative } \\ \text { internal con- } \\ \text { centration. }\end{array} & \text { Weight in grm. } \\ 0 & 0.1 & 0.0 & \\ 5 & 0.08 & 0.02 & 1.04 \\ 24 & 0.06 & 0.04 & 0.86 \\ 48 & 0.06 & 0.04 & 0.81 \\ 0 & 0.05 & 0.0 & 0.78 \\ 5 & 0.035 & 0.015 & 0.87 \\ 24 & 0.03 & 0.02 & 0.75 \\ 48 & 0.03 & 0.02 & 0.68 \\ 0 & 0.01 & 0.0 & 0.67 \\ 5 & 0.007 & 0.003 & 0.96 \\ 24 & 0.004 & 0.006 & 0.93 \\ 48 & 0.002 & 0.008 & 0.92 \\ 72 & 0.0009 & 0.0091 & 0.90 \\ 96 & 0.0007 & 0.0093 & 0.90 \\ 144 & 0.0005 & 0.0095 & 0.89 \\ 0 & 0.005 & 0.0 & 0.87 \\ 5 & 0.0025 & 0.0025 & 1.06 \\ 24 & 0.0015 & 0.0035 & 1.06 \\ 48 & 0.00085 & 0.00415 & 1.06 \\ 72 & 0.0004 & 0.0046 & 1.05 \\ 96 & 0.000225 & 0.00475 & 1.06 \\ 144 & 0.000125 & 0.004875 & 1.05 \\ 4 & & 1.05\end{array}$

At the end of the experiments in this series a slight yellowish tinge was observed; this showed that the external solution was becoming acid.

TABlE II. Absorption of Dye, by living Carrot Tissue, from Solutions of Various Concentrations.

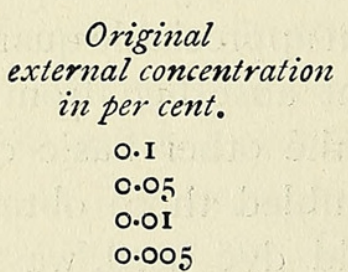

$\begin{aligned} & \text { Neutral } \\ & \text { red. }\end{aligned}$
0.06
0.03
0.0005
0.000125

Final external concentration in per cent.-

blue.

0.032

0.012

0.0008

0.0003

\section{Methy}

violet.

0.03

0.01

0.0018

0.001

$\begin{array}{ll}\begin{array}{l}\text { Aniline } \\ \text { blue. }\end{array} & \text { Eosin. } \\ 0.1 & 0.1 \\ 0.045 & 0.045 \\ 0.008 & 0.008_{5} \\ 0.003 & 0.004\end{array}$


TABLE III. Absorption of Dye, by living Tissue of other Species, from Solutions of Various Concentrations.

\begin{tabular}{cccc} 
Original & \multicolumn{3}{c}{ Final external concentration in per cent. } \\
external concentration & Neutral red. & Methylene blue. & Methyl violet. \\
in per cent. & Potato. & Artichoke. & Turnip. \\
0.1 & 0.085 & 0.04 & 0.08 \\
0.05 & 0.018 & 0.007 & 0.03 \\
0.01 & 0.0019 & 0.0027 & 0.0025 \\
0.005 & 0.0008 & 0.0006 & 0.001
\end{tabular}

If the relation between the final external concentrations and the final internal concentrations corresponds to the adsorption equation $y=k c^{\frac{1}{m}}$, where $y=$ final internal concentration, $c=$ final external concentration, and $k$ and $m$ are constants, then the graph obtained by plotting the logarithm of

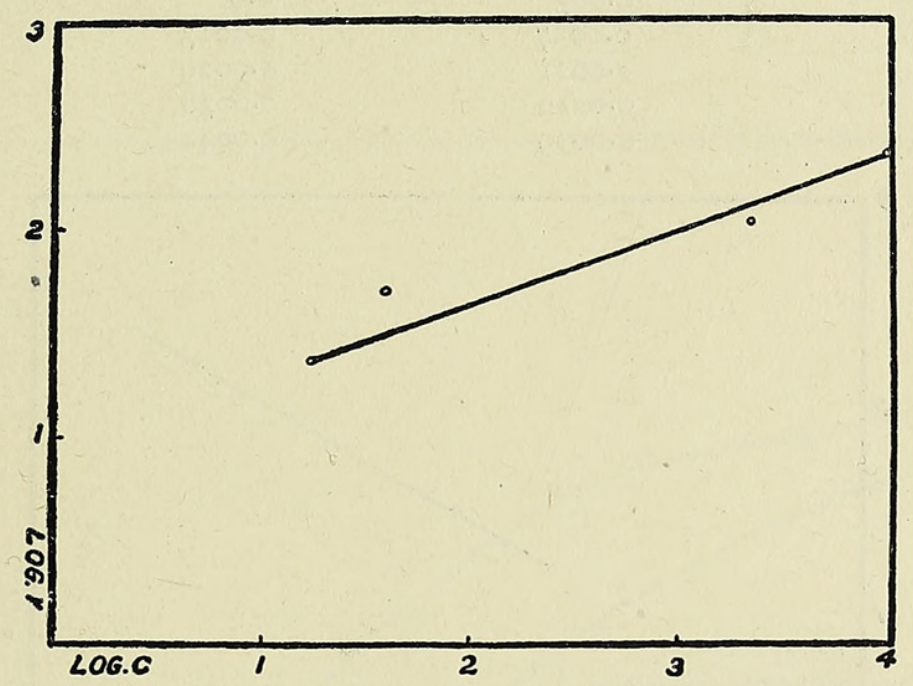

FIG. 2. The relation between final internal and final external concentrations in the case of living carrot tissue immersed in solutions of neutral red.

the final external concentration against the logarithm of the final internal concentration will approximate to a straight line. This was the case in most of the experiments with carrot tissue; in Figs. 2 and 3 the graphs for neutral red and methylene blue are so plotted. In the case of tissues other than carrot, however, the results differed somewhat; Fig. 4 shows the graph for neutral red, in which discs of potato tissue were immersed. Similar figures were given by the results obtained with artichoke and turnip tissue.

\section{Series 2. Experiments with dead tissue.}

These experiments were carried out with discs of carrot tissue, which were killed in a mixture of acetic acid and absolute alcohol ; they were then thoroughly washed and transferred to the experimental dye solutions. Two sets of experiments were made, one with methylene blue and one with methyl violet. The results with methylene blue are summarized in Table IV, and the course of absorption is plotted in Fig. 5 . 
T ABLE IV. Absorption of Methylene Blue, by Discs of Dead Carrot Tissue, from Solutions of Various Concentration.

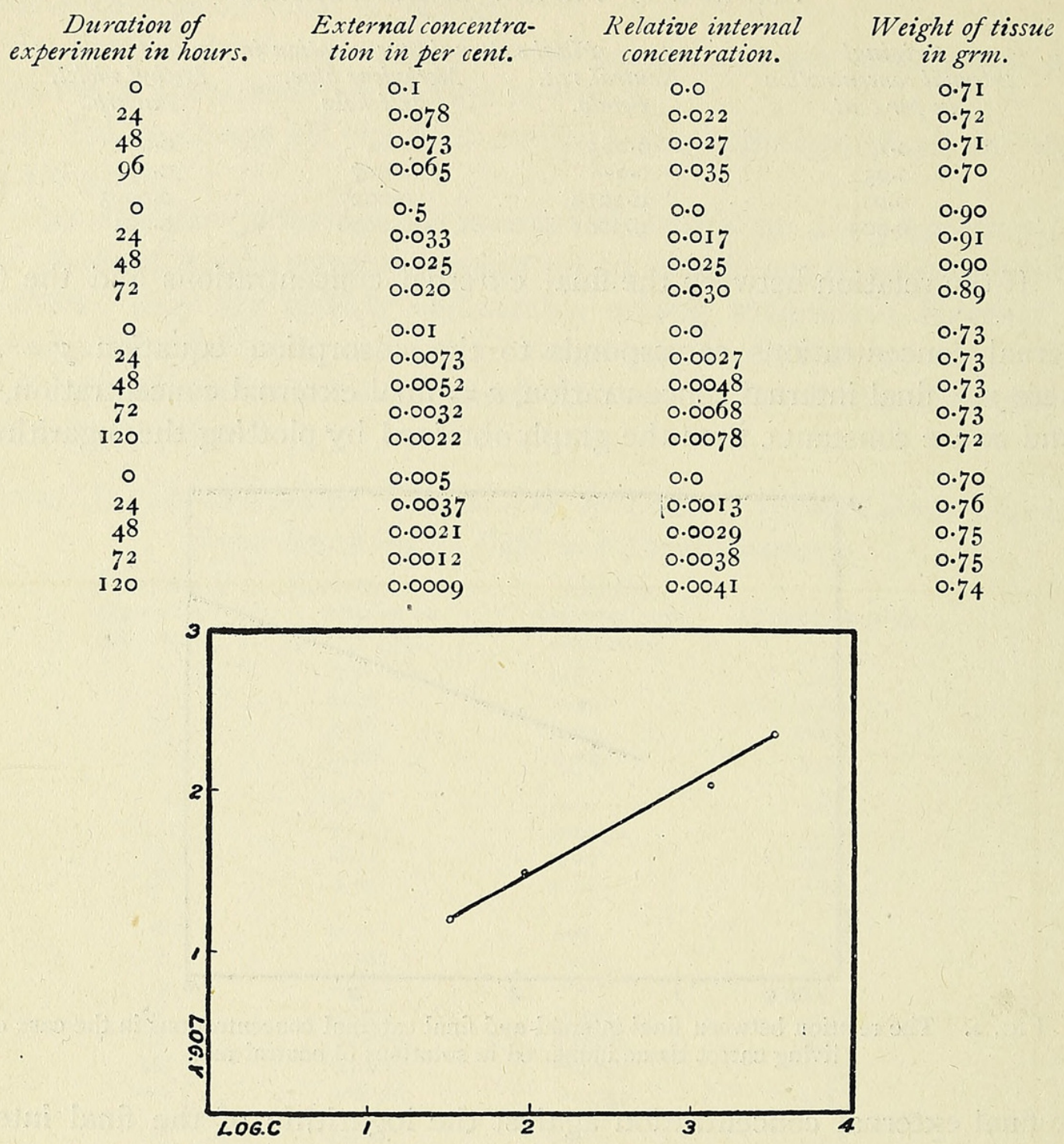

FIG. 3. The relation between final external and final internal concentrations in the case of living carrot tissue immersed in solutions of methylene blue.

Similar results were obtained with methyl violet, though the proportion of dye absorbed by the tissue in this case was slightly less. The final external concentrations for both dyes are set out in Table V, and in Fig. 6 the logarithm of the final external concentration is plotted against the logarithm of the final internal concentration in the case of methylene blue.

TABle V. Absorption of Dye, by Dead Carrot Tissue, from Solutions of Various Concentrations.

Original external concentration in per cent.

$$
\begin{aligned}
& 0.1 \\
& 0.05 \\
& 0.01 \\
& 0.005
\end{aligned}
$$

Final external concentration in percent.Methylene blue. Methyl violet. 0.065

0.02

0.0022 0.0009
0.065

0.025

0.003

0.0013 
Equilibrium in the Intake of Dyes by Discs of Plant Tissue. 517

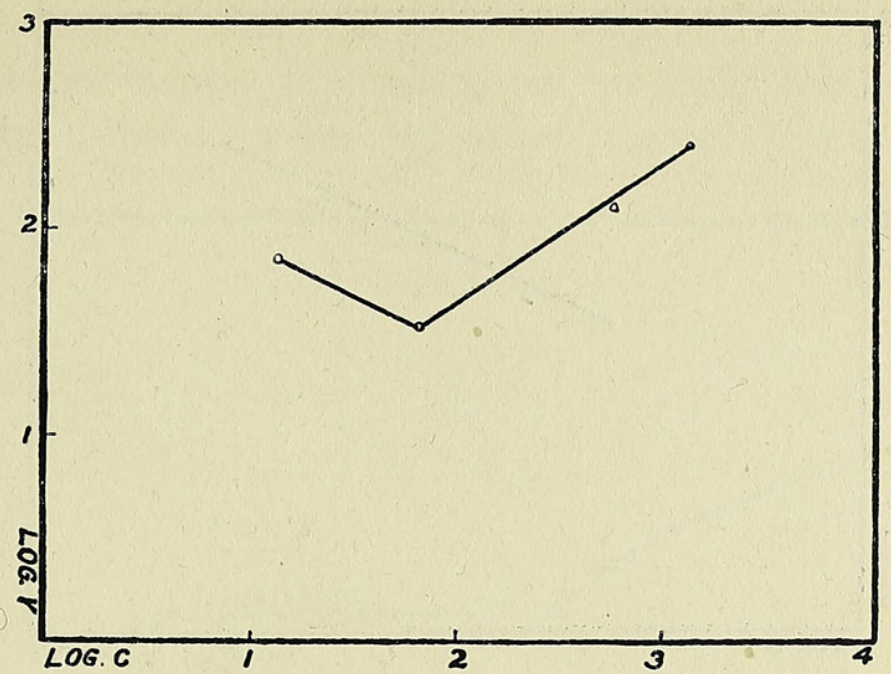

FIG. 4. The relation of final external and final internal concentrations in the case of potato tissue immersed in solutions of neutral red.

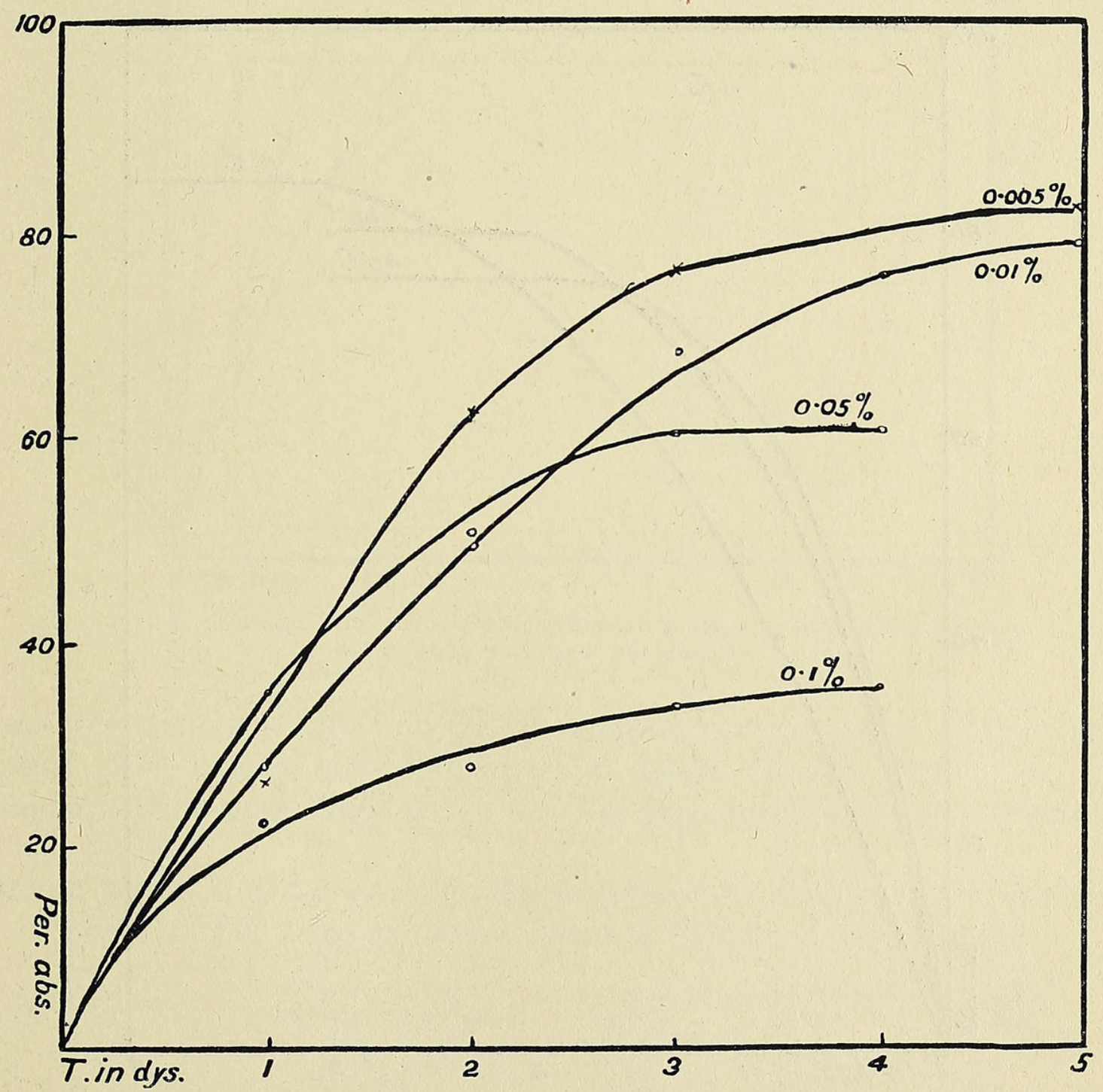

FIG. 5. Absorption of methyiene blue from solutions of various concentrations by dead carrot tissue. 
518 Redfern.-On the Course of Absorption and the Position of

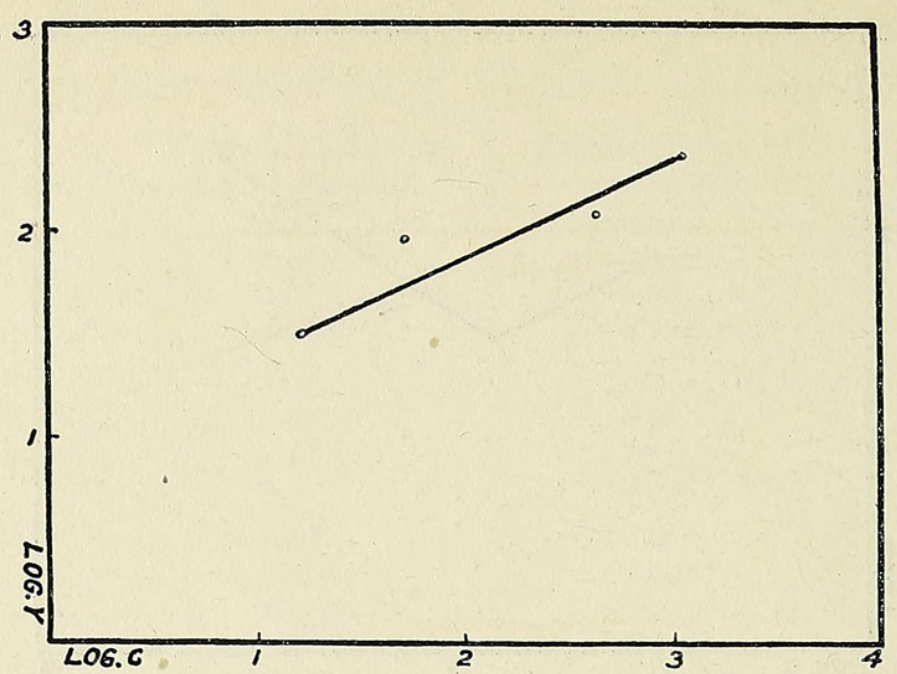

FIG. 6. Relation of final internal and final external concentrations in the case of dead carrot tissue immersed in solutions of methylene blue.

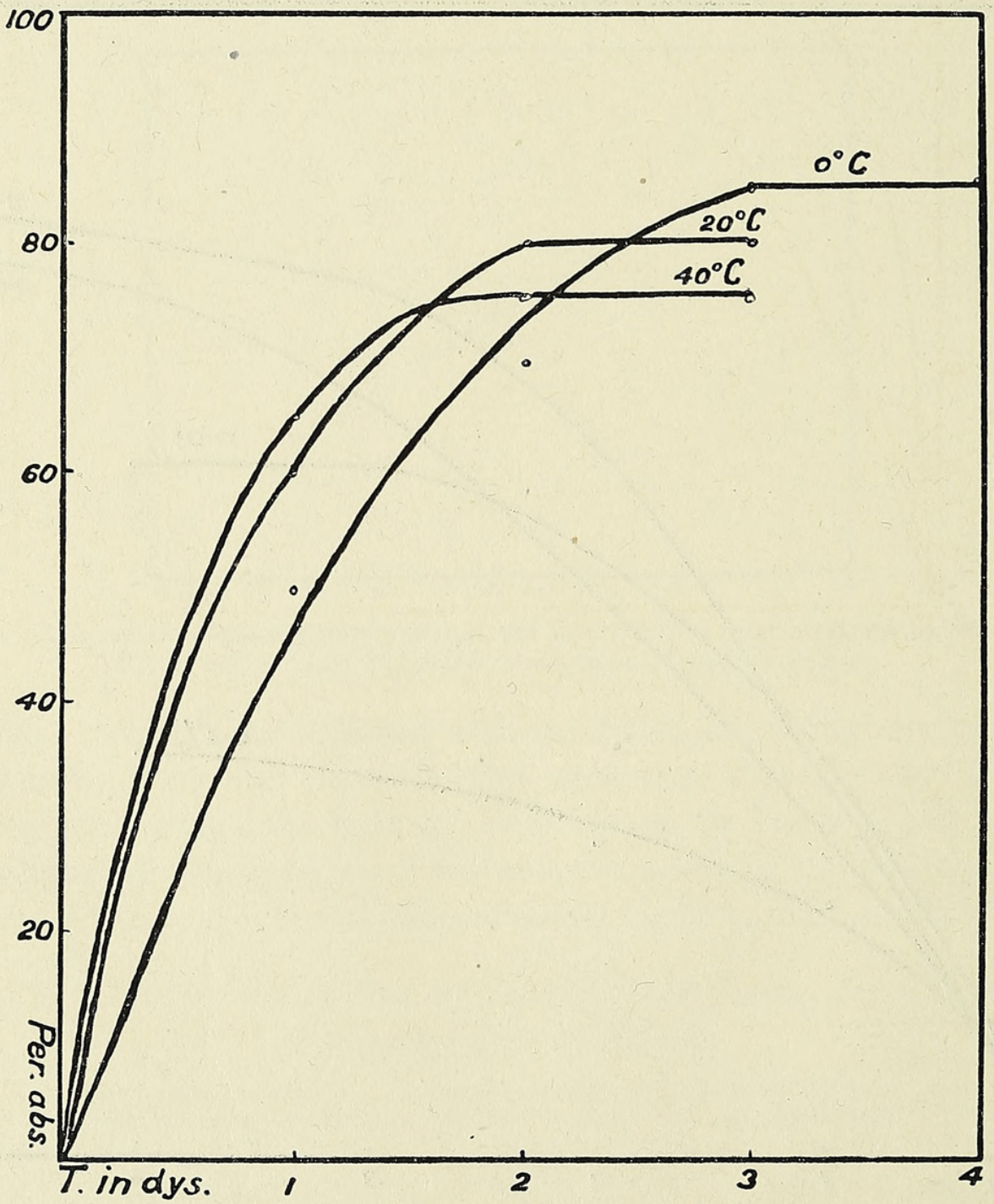

FIG. 7. Absorption of methylene blue from 0.0 I per cent. solution by living carrot tissue at different temperatures. 
Series 3. Experiments to test the effect of temperature.

Series of experiments were carried out, in which the bottles containing the experimental solutions were kept at $40^{\circ} \mathrm{C}$, $20^{\circ} \mathrm{C}$., and $0^{\circ} \mathrm{C}$. The dye

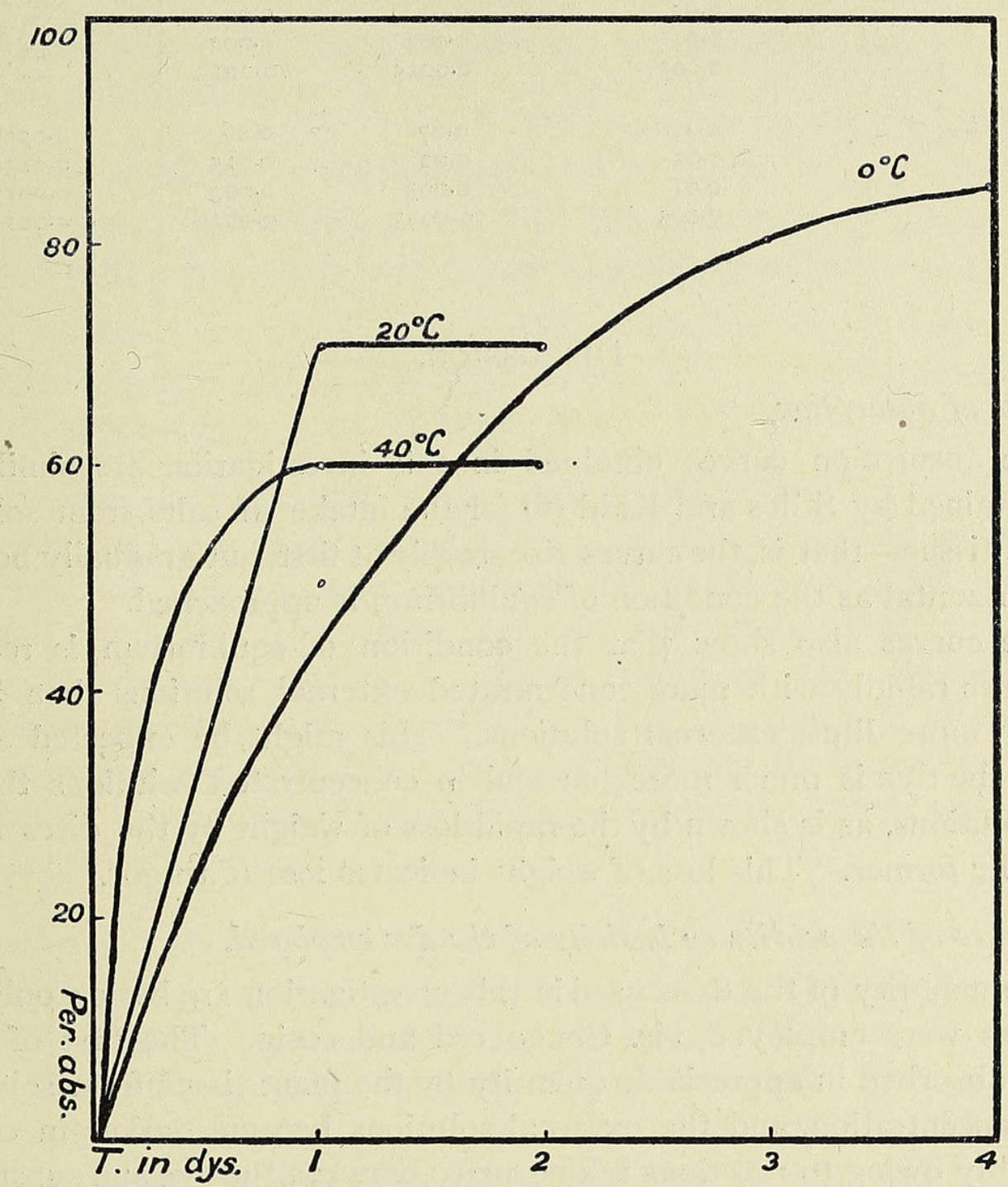

FIG. 8. Absorption of methylene blue from 0.005 per cent. solution by living carrot tissue at different temperatures.

used was methylene blue, and the experiments were made with living carrot tissue. The results are summarized in Table VI and Figs. 7 and 8. Similar results were obtained in a series of experiments with methyl violet.

TABLE VI. Absorption of Methylene Blue from Solutions of Different ${ }^{\circ}$ Concentrations by Discs of Carrot Tissue at Different Temperatures.

Temperature. $40^{\circ} \mathrm{C}$.
Original external concentration in per cent.

$\begin{array}{ll}0.1 & 0.07 \\ 0.05 & 0.025 \\ 0.01 & 0.0035 \\ 0.005 & 0.002\end{array}$

External concentration in per cent. after24 hrs. $\quad 48$ hrs. 72 hrs.

$0.07: 0.06$

0.02

0.0025

0.002 


\begin{tabular}{ccccc}
\multicolumn{5}{c}{ TABLE VI (continued). } \\
Temperature. & $\begin{array}{c}\text { Original external con. } \\
\text { centration in per cent. }\end{array}$ & \multicolumn{2}{c}{ External concentration in per cent. after- } \\
24 hrs. & 48 hrs. & 72 hrs. \\
$20^{\circ} \mathrm{C}$. & 0.1 & 0.07 & 0.07 & - \\
& 0.05 & 0.03 & 0.02 & - \\
& 0.01 & 0.004 & 0.002 & - \\
& 0.005 & 0.0015 & 0.0015 & - \\
$0{ }^{\circ} \mathrm{C}$. & 0.1 & 0.07 & 0.06 & 0.055 \\
& 0.05 & 0.02 & 0.015 & 0.015 \\
& 0.01 & 0.005 & 0.003 & 0.0015 \\
& 0.005 & 0.0025 & 0.002 & 0.001
\end{tabular}

\section{Discussion.}

I. Course of absorption.

The absorption curves obtained in this investigation are similar to those obtained by Stiles and Kidd (6) for the intake of salts from solution by plant tissue-that is, the curves rise steeply at first, but gradually become more horizontal as the condition of equilibrium is approached.

The curves also show that the condition of equilibrium is reached much more rapidly with more concentrated external solutions than is the case with more dilute external solutions. This might be expected as the effect of the dye is much more harmful in concentrated solutions than in dilute solutions, as is shown by the rapid loss of weight by the discs in the case of the former. This loss of weight indicates loss of turgor.

\section{Influence of the acidity or basicity of the dye employed.}

The majority of the dyes used in this investigation are basic; only two acid dyes were employed, viz. Congo red and eosin. The first of these was not absorbed in appreciable quantity by the plant tissue from solutions of any concentration, and the external solutions became darker in colour, presumably owing to reactions taking place between the dye and substances which diffuse out from the cells. In the case of eosin, the dye was not appreciably absorbed from the more concentrated solutions, and only to a slight extent from the more dilute solutions.

The basic dyes, on the contrary, with one exception (aniline blue), were rapidly absorbed, and when equilibrium was reached the internal concentration was frequently greater than the external concentration, especially in the case of the more dilute solutions.

These results are in accord with the earlier ones of Ruhland (5), who found that basic dyes were rapidly absorbed, while acidic dyes were, at most, absorbed to a very slight extent. The results also agree with those of Collander (1) in his recent work on the sulphonic acid dyes. He found that these dyes were absorbed in relatively slight amounts by plant tissue. In an extensive series of experiments, he estimated the ratio between the 
internal concentration and the external concentration of the dye when equilibrium was reached. He found that in many cases the ratio was of the order

$$
\frac{x}{y}=\frac{\mathrm{I}}{\mathrm{I} 20}, \text { or } \frac{\mathrm{I}}{240} \text {, }
$$

or even less, where $x=$ the final internal concentration, and $y=$ the final external concentration.

\section{Influence of the size of the molecule.}

The dyes which were employed in the present investigation may be classified with regard to the size of the molecule, as follows:-

\section{Colloid}

Congo red

Aniline blue
Semi-colloid

Methyl violet

Neutral red
Crystalloid

Methylene blue

Eosin

It is evident, therefore, that in the case of crystalloids and semi-colloids, the size of the molecule has little influence in determining the amount of the dye absorbed; this is in agreement with the earlier conclusions reached by Ruhland (5), though in his later work he completely altered his attitude. Neither of the dyes classed as colloids, however, was absorbed in any appreciable quantity; the case of aniline blue is especially interesting, as this dye is basic, and was the only basic dye investigated which was not rapidly absorbed. It is noteworthy that Pfeffer recorded the fact that aniline blue is not absorbed by plant tissue.

\section{Comparison of the results obtained with living and dead tissue.}

If the results recorded in Table II are compared with those in Table V, it will be seen that the discs of dead tissue behaved in a very similar manner to the discs of living tissue. In every experiment the absorption was slightly less in the case of dead tissue; however, in view of the low degree of accuracy obtainable with the colorimetric method used, and also in consideration of the variability of plant tissue, it is probable that this difference cannot be regarded as significant.

It is a possibility that with discs of living tissue the dye is chiefly absorbed by the superficial dead cells, but examination of sections under the microscope showed that the dye penetrated to the internal living cells.

\section{Effect of temperature.}

As only a few experiments were made to test the effect of temperature, no definite conclusions can be drawn. It is interesting to note, however, that the percentage absorption of the dye is increased with decrease of temperature; this is especially marked in the case of the more dilute solutions. This effect of temperature is characteristic of adsorption processes as distinct from chemical combinations. 


\section{Influence of the concentration of the external solution.}

The results given above show that the percentage absorption of the dye is increased as the external solution becomes more dilute. This is very clearly shown in the case of the basic dyes, which were absorbed from all concentrations; in the case of the acid dyes and aniline blue, if there was any appreciable absorption it only took place in the more dilute solutions.

When the logarithm of the final external concentration is plotted against the logarithm of the final internal concentration the resulting graph approximates to a straight line, in the case of most of the basic dyes and eosin. This indicates that the relation between these concentrations corresponds to the adsorption equation $y=k c^{\frac{1}{m}}$, where $y=$ final internal concentration, $c=$ final external concentration, and $k$ and $m$ are constants. Although this fact cannot be taken as proof that the absorption of dyes by plant tissue is a process of adsorption, yet it may be regarded as evidence in favour of the view that adsorption plays an important part in the absorption process; the results obtained in the few experiments carried out at different temperatures support this view. In several cases, however, notably with tissue other than carrot, the process seems to be complicated by some other reaction, possibly one of chemical combination.

\section{LITERATURE CITED.}

1. Collander, R. : Über die Permeabilität pflanzlicher Protoplasten für Sulfosäurefarbstoffe. Jahrb. für wiss. Bot., lx. 354-410, I921.

2. Moore, B., and Roaf, H. E. : Direct Measurement of the Osmotic Pressure of certain Colloids. Biochem. Journ., ii $34-73$, 1907 .

3. - Roaf, H. E., and Webster, T. A.: Direct Measurement of the Osmotic Pressure of Casein in Alkaline Solution. Biochem. Journ., vi. I 10-26, 1912.

4. Pfeffer, W. : Über Aufnahme von Anilinfarben in die lebende Zelle. Unters. a. d. Bot. Inst. z. Tübingen, ii. $179-33^{2}$, I 886 .

5. Ruhland, W.: Die Bedeutung der Kolloidalnatur wässriger Farbstoffe für ihr Eindringen in die lebende Zelle. Ber. der deut. bot. Ges., xxvi a. 772-82, 1908.

6. Stiles, W., and KIDD, F. : The Influence of the External Concentration on the Position of the Equilibrium attained in the Intake of Salts by Plant Cells. Proc. Roy. Soc., B., xc. 44870, 1919.

7. $\longrightarrow$, and Jørgensen, I. : Studies in Permeability, I. Ann. Bot., xxix. 349-67, 191 5. 


\section{$2 \mathrm{BHL}$ Biodiversity Heritage Library}

Redfern, Gladys M. 1922. "On the course of absorption and the position of equilibrium in the intake of dyes by discs of plant tissue." Annals of botany 36, 511-522. https://doi.org/10.1093/oxfordjournals.aob.a089820.

View This Item Online: https://www.biodiversitylibrary.org/item/234428

DOI: https://doi.org/10.1093/oxfordjournals.aob.a089820

Permalink: https://www.biodiversitylibrary.org/partpdf/319057

\section{Holding Institution}

Smithsonian Libraries

\section{Sponsored by}

Biodiversity Heritage Library

\section{Copyright \& Reuse}

Copyright Status: Not in copyright. The BHL knows of no copyright restrictions on this item.

This document was created from content at the Biodiversity Heritage Library, the world's largest open access digital library for biodiversity literature and archives. Visit BHL at https://www.biodiversitylibrary.org. 